\title{
EVALUASI DAN ANALISIS PELAKSANAAN MUSYAWARAH MASYARAKAT KELURAHAN DI WILAYAH PUSKESMAS X SURABAYA
}

\section{VILLAGE COMMUNITY DELIBERATION EVALUATION AND ANALYSIS IN X PUBLIC HEALTH CENTER}

\section{Malida Nurul Hidayah}

Badan Kependudukan dan Keluarga Berencana Nasional

E-mail: nurulmalida@gmail.com

\begin{abstract}
Background: Ministry of Health Republic of Indonesia create a vision in health development that is "Independent and Justice of Healthy Community". The embodiment of the mission statement is poured in the form of a strategic programs which is District Alert programs through Village Community Deliberation and Community Self Survey. Purpose: The purpose of this study is to evaluate the implementation of Village Community Deliberation I and II of 2017 year in X Community Health Center. Methods: This type of research is descriptive observational. Data collection techniques used through interviews and secondary data collection. Methods of data analysis are done by doing a comparison between the data already obtained with the theory and guidelines in the implementation of research materials. This study lasted on February 26, 2018 - March 4, 2018. Results: Terms of implementers are still not in accordance with existing provisions, while for SMD executor already corresponding. In the aspect of the implementation of MMK and SMD is in accordance with the intended purpose as well as the results or output expected at the all stage. Conclusion: The stages of activities have held with appropriate the standards of existing regulations in Village Community Deliberation and Community Self Survey.
\end{abstract}

Keywords: Village Community Deliberation, Community Self Survey, evaluation, district, alert

\begin{abstract}
ABSTRAK
Latar Belakang: Kementerian Kesehatan Republik Indonesia menjadikan visi dalam pembangunan kesehatan yaitu "Masyarakat Sehat yang Mandiri dan Berkeadilan". Perwujudan pernyataan misi tersebut dituangkan dalam bentuk sebuah upaya strategis yakni melalui program Kelurahan siaga aktif melalui musyawarah masyarakat kelurahan dan survey mawas diri. Tujuan: Tujuan penelitian ini adalah melakukan evaluasi dan analisis pelaksanaan Musyawarah masyarakat kelurahan I dan II tahun 2017 di wilayah kerja Puskesmas X. Metode: Jenis penelitian ini adalah observasional Deskriptif. Teknik pengumpulan data yang digunakan melalui wawancara dan pengumpulan data sekunder. Metode analisis data dilakukan dengan cara melakukan perbandingan antara data yang sudah didapat dengan teori maupun pedoman dalam pelaksanaan materi penelitian. Penelitian ini berlangsung selama satu minggu pada 26 Februari 2018 - 4 Maret 2018. Hasil: Pelaksanaan musyawarah masyarakat kelurahan dan Survei mawas diri di wilayah Puskesmas $X$ dari segi pelaksana belum sesuai dengan ketentuan yang ada, sedangkan untuk SMD pelaksana-nya sudah sesuai. Pada aspek pelaksanaan Musyawarah Masyarakat Kelurahan dan Survei Mawas Diri sudah sesuai dengan tujuan yang telah ditetapkan begitu pula dengan hasil atau keluaran yang diharapkan pada tahapan MMK I, SMD, dan MMK II. Kesimpulan: Tahapan kegiatan dalam kelurahan siaga meliputi musyawarah masyarakat kelurahan I dan II telah dilaksanakan dengan sesuai standar, dan pelaksanaan SMD juga dikatakan telah memenuhi standar dari peraturan yang ada.
\end{abstract}

Kata Kunci: Musyawarah Masyarakat Kelurahan, Survei Mawas Diri, evaluasi, kelurahan, siaga 


\section{PENDAHULUAN}

Undang-undang Republik Indonesia Nomor 17 Tahun 2007 tentang pembangunan Jangka Panjang Nasional untuk tahun 20052025 menyatakan bahwa visi pembangunan nasional adalah "Indonesia yang mandiri, maju, adil, dan makmur”. Untuk mencapai visi tersebut, pembangunan jangka panjang diutamakan menuju delapan arah pembangunan. Delapan arah pembangunan ini salah satunya diupayakan dalam meningkatkan Indeks Pembangunan Manusia (IPM). Komponen dalam pembangunan manusia yang dimaksud mencakup berbagai aspek yakni derajat kesehatan, tingkat pendidikan, dan pertumbuhan ekonomi, sehingga dalam visi dari masingmasing aspek tersebut tidak lepas dari upaya untuk menjadikan masyarakat Indonesia dapat lebih mandiri. Salah satu bentuk kemandirian masyarakat adalah membangun derajat kesehatan masyarakat Indonesia.

Kementrian Kesehatan Republik Indonesia menjadikan visi dalam pembangunan kesehatan yaitu "Masyarakat Sehat yang Mandiri dan Berkeadilan". Visi tersebut dijabarkan dalam empat misi utama perwujudan pembangunan kesehatan di Indonesia. Misi pertama menyatakan bahwa peningkatan derajat kesehatan dilaksanakan melalui pemberdayaan masyarakat, swasta, serta masyarakat madani baik untuk tingkat nasional hingga global. Perwujudan pernyataan misi tersebut dituangkan dalam bentuk sebuah upaya strategis yakni melalui program desa siaga aktif yang dilaksanakan di seluruh wilayah Indonesia. Program strategis ini pertama kali dikembangkan dalam Keputusan Menteri Kesehatan Nomor 564/ Menkes/SK/VIII/2006 Tentang Pedoman Pelaksanaan Pengembangan Desa Siaga. Pada dasarnya upaya memandirikan masyarakat dalam aspek kesehatan telah gencar dilakukan pemerintah sejak tahun 1970-1980an. Pada dasawarsa tersebut pemerintah mampu menghimpun peran aktif masyarakat di bidang kesehatan yang diwujudkan dalam gerakan Pembangunan Kesehatan Masyarakat Desa (PKMD). Pelaksanaan PKMD tersebut membutuhkan kerjasama dengan berbagai sektor terkait, diantaranya sektor pemerintahan, swasta, lembaga masyarakat serta pemangku dan pengambil keputusan maupun masyarakat desa itu sendiri. Program peningkatan kemandirian masyarakat tersebut terus mengalami perkembangan hingga dicanangkanlah program desa siaga aktif. Program desa siaga aktif dalam perkembangannya terus mengalami penyesuaian, dimana sebagian besar desa saat ini telah menjadi kelurahan, maka untuk meningkatkan kualitas pelaksanaan ditegaskan bahwa desa siaga aktif juga merupakan kelurahan siaga aktif.

Definisi kelurahan siaga aktif dalam Keputusan Menteri Kesehatan Nomor 564/ Menkes/SK/VIII/2006 adalah program yang dilaksanakan dengan konsep pendekatan kebersamaan. Hal tersebut sebagai usaha dalam menyelenggarakan pencapaian peningkatan derajat kesehatan bagi seluruh penduduk dengan mengembangkan sebuah program masyarakat yang mandiri atau siaga di tingkat kelurahan.

Peraturan terbaru yang dijadikan sebagai acuan utama dalam pelaksanaan program ini adalah pedoman pelaksanaan kelurahan siaga yang diatur melalui Keputusan Menteri Kesehatan Republik Indonesia Nomor 1529/MENKES/SK/X/2010. Kelurahan siaga dalam hal ini mencakup berbagai program strategis yang tercantum dalam pedoman. Terdapat 3 komponen penting yang menjadi patokan pelaksanaan kelurahan siaga aktif adalah 1) pelayanan kesehatan dasar, 2) pemberdayaan masyarakat melalui pengembangan Upaya Kesehatan Bersumber daya Masyarakat (UKBM) dan mendorong upaya surveilans berbasis masyarakat, kedaruratan kesehatan dan penanggulangan bencana dan penyehatan lingkungan, 3) Perilaku Hidup Bersih dan Sehat (PHBS).

Pelayanan kesehatan dasar dalam kelurahan siaga aktif digalakkan melalui UKBM serta partisipasi aktif dari kader yang pada umumnya dibina dibawah naungan kelurahan dengan bantuan pihak puskesmas. Pelaksanaan UKBM ini didukung oleh sarana kesehatan yang ada, seperti puskesmas dan rumah sakit. Pemberdayaan masyarakat menjadi dasar pendekatan utama dalam pelaksanaan kelurahan siaga aktif. Aspek utama dalam pemberdayaan masyarakat adalah keterlibatan masyarakat secara langsung pada semua tahapan pelaksanaan program. Hal tersebut dapat terlihat dari peran aktif kader dalam upaya 
membantu kegiatan surveilans kesehatan yang berbasis masyarakat.

Kedaruratan kesehatan dan penanggulangan bencana merupakan upaya-upaya dalam menanggulangi bencana dengan mengacu pada pedoman teknis dari instansi kesehatan yang ada. Upaya penyehatan lingkungan mencakup upaya masyarakat dalam memelihara kondisi lingkungan kelurahan agar lingkungan sehat dan tidak menjadi sarang penyakit yang menimbulkan masalah kesehatan. Penerapan PHBS juga merupakan upaya penyehatan lingkungan yang dapat dilakukan di tingkat rumah tangga, institusi pendidikan, tempat umum, tempat kerja serta berbagai sarana lain terutama sarana kesehatan.

Komponen utama dari penyelenggaraan kelurahan siaga sesuai dengan konsep pemberdayaan, yaitu partisipasi aktif masyarakat sebagai penyelenggara utama. Instansi terkait dilibatkan dari berbagai tingkatan mulai dari tingkat pusat yaitu kementrian kesehatan hingga tingkat yang paling kecil yaitu desa/kelurahan. Berdasarkan pedoman pelaksanaan kelurahan siaga, yaitu Keputusan Menteri Kesehatan Republik Indonesia Nomor 1529/ MENKES/SK/X/2010 pada Bab IV poin E, susunan peran pelaksanaan kelurahan siaga diketuai oleh lurah, dengan anggota unsur kelembagaan masyarakat tingkat kelurahan meliputi unsur lembaga agama, pendidikan, penggerak PKK, serta kader kesehatan dengan dibantu puskesmas sebagai pembina.

Komponen yang telah dijabarkan sebelumnya menjadi dasar tujuan pelaksanaan kelurahan siaga aktif yang dituangkan ke dalam berbagai tahap pelaksanaan. Tahapan pelaksanaan tersebut meliputi 1) pengenalan kondisi lingkungan kelurahan, 2) identifikasi masalah kesehatan dan PHBS, 3) musyawarah kelurahan, 4) perencanaan partisipatif, serta 5) pelaksanaan kegiatan. Tahap ketiga, yakni musyawarah kelurahan, dalam realita pelaksanaannya terbagi menjadi dua bagian, yakni musyawarah masyarakat kelurahan I (MMK) I dan musyawarah masyarakat kelurahan (MMK) II. MMK ini dapat dikatakan sebagai komponen utama dalam pelaksanaan kelurahan siaga, karena mencakup tindakan pertama dalam tahapan kelurahan siaga yaitu persiapan petugas dan persiapan lapangan.

Pada pelaksanaan di lapangan, tahapan kegiatan kelurahan siaga tidak selalu mengikuti tahapan yang dijabarkan dalam pedoman. Setiap kelurahan dapat melaksanakan tahapan yang telah disesuaikan dengan kondisi pada kelurahan masing-masing. Kota Surabaya merupakan salah satu kota di Jawa Timur yang turut melaksanakan kelurahan siaga. Pelaksanaan kelurahan siaga Kota Surabaya umumnya memiliki empat tahapan utama yakni sebagai berikut : 1) musyawarah masyarakat kelurahan I 2) pelaksanaan survei mawas diri (SMD), 3) pelaksanaan rencana tindak lanjut, dan 4) musyawarah masyarakat kelurahan II.

Pelaksanaan tahapan musyawarah masyarakat kelurahan I dan II sendiri menjadi tahapan yang diharapkan mampu untuk mewujudkan konsep kelurahan siaga aktif yang bersumber daya peran aktif masyarakat. Musyawarah masyarakat kelurahan I dan II merupakan pertemuan tingkat kelurahan yang diikuti oleh perwakilan kelurahan, perwakilan RT dan RW, puskesmas, dan kader kesehatan dalam satu ruangan. Perbedaan dari keduanya adalah musyawarah masyarakat kelurahan I tujuan utamanya adalah melakukan pembahasan daftar masalah kesehatan yang ada di kelurahan berdasarkan diskusi dengan masing-masing perwakilan Tingkat RW maupun RT serta melakukan skala prioritas daftar masalah yang telah didapat melalui sebuah bentuk diskusi besar, sedangkan dalam musyawarah masyarakat kelurahan II tujuannya adalah melakukan pembahasan mengenai hasil pelaksanaan Survei mawas diri pada masing-masing kelurahan sebagai tindak lanjut MMK I untuk dibuat sebuah rencana tindak lanjut dalam mengatasi permasalahan yang ditemukan dari pelaksanaan SMD. Pembahasan permasalahan pada umumnya dilakukan dengan membahas permasalahan dari masing-masing RW dalam kelurahan tersebut, sehingga rencana tindak lanjut yang dibuat itu dapat berbeda pada masingmasing RW sesuai dengan kesepakatan peserta MMK II yang telah hadir.

Puskesmas $X$ sendiri berada di bawah naungan Dinas Kesehatan Kota Surabaya, sehingga turut dalam melaksanakan program kelurahan siaga. Salah satu 
program yang dilaksanakan oleh Puskesmas $\mathrm{X}$ adalah musyawarah masyarakat kelurahan I dan II serta kegiatan survei mawas diri. Sebagai salah satu instansi yang terkait dengan pelaksanaan kelurahan siaga dan mengikuti tahapan musyawarah masyarakat kelurahan I dan II serta survei mawas diri, maka perlu dilakukan evaluasi dalam pelaksanaannya yang dilihat dari segi peran puskesmas.

Tujuan penelitian ini adalah melakukan evaluasi dan analisis pelaksanaan musyawarah masyarakat kelurahan I dan II tahun 2017 di wilayah kerja Puskesmas X dengan berpedoman pada hasil wawancara Bidan Kelurahan dan peraturan terkait pelaksanaan musyawarah masyarakat kelurahan yang dituangkan oleh pemerintah dalam beberapa peraturan.

\section{METODE}

Jenis penelitian ini adalah observasional, dimana data diperoleh dari wawancara dan observasi terhadap obyek di lapangan, serta tidak diberi perlakuan sama sekali (Notoadmojo, 2012). Menurut jenisnya, penelitian ini termasuk dalam penelitian deskriptif dimana penelitian bertujuan untuk menjelaskan serta menggambarkan fenomena tanpa dilakukan analisis mengenai kejadian dalam fenomena tersebut. Jenis penelitian deskriptif yang digunakan adalah studi evaluasi, yaitu studi yang bertujuan dalam menilai suatu kegiatan atau program, dimana hasil deskripsi evaluasi yang telah dilakukan dapat dijadikan sebagai pedoman untuk perbaikan maupun upaya meningkatkan keberhasilan program (Widyaningsih, 2008).

Sumber data yang digunakan untuk penelitian ini adalah data primer serta data sekunder. Data primer mencakup hasil wawancara yang didapat melalui kegiatan wawancara kepada bidan kelurahan selaku penanggung jawab pelaksanaan kelurahan siaga aktif termasuk kegiatan musyawarah masyarakat kelurahan. Data sekunder didapat dari dokumen pelaporan musyawarah masyarakat kelurahan I dan II, serta laporan pelaksanaan Survei Mawas Diri (SMD) pada tahun pelaksanaan 2017 yang dilakukan oleh puskesmas $X$.

Teknik pengumpulan data yang digunakan dalam penelitian ini melalui wawancara yang dilakukan terhadap bidan kelurahan, dimana bidan kelurahan ini merupakan staf puskesmas yang terlibat dalam pelaksanaan kelurahan siaga aktif, serta kegiatan musyawarah masyarakat kelurahan. Selain hasil wawancara, pengambilan data didapatkan melalui pengumpulan data sekunder yakni dokumen laporan musyawarah masyarakat kelurahan I dan II, serta laporan pelaksanaan survei mawas diri Tahun 2017 di wilayah kerja puskesmas X.

Metode analisis data dilakukan dengan cara melakukan perbandingan antara data yang sudah didapat dengan teori maupun pedoman dalam pelaksanaan materi penelitian. Terkait dengan hal tersebut, hasil wawancara serta dokumen yang telah didapat dibandingkan dengan teori pemberdayaan masyarakat menurut Soekanto, Pedoman Pelaksanaan Kelurahan Siaga dalam Keputusan Menteri Kesehatan Republik Indonesia Nomor 1529/MENKES/ SK/X/2010 terkhusus pada poin pelaksanaan Musyawarah masyarakat kelurahan, PMK No.44 Tahun 2016 tentang Pedoman Manajemen Puskesmas, dan Juknis biaya pengembangan desa siaga aktif.

Penelitian ini berlokasi di wilayah kerja puskesmas X Surabaya yang mencakup tiga wilayah kelurahan, yaitu kelurahan A, Kelurahan B, dan Kelurahan C. Penelitian ini berlangsung selama satu minggu pada 26 Februari 2018 - 4 Maret 2018. Waktu pelaksanaan kegiatan disesuaikan dengan kebutuhan pengambilan data, yang terbagi ke dalam beberapa kegiatan sebagai berikut, yaitu : 1) wawancara terhadap bidan kelurahan, 2) pengambilan dokumen laporan hasil kegiatan MMK I dan II tahun 2017 serta laporan hasil kegiatan SMD tahun 2017.

\section{HASIL DAN PEMBAHASAN}

Pedoman Pelaksanaan Kelurahan Siaga dalam Keputusan Menteri Kesehatan Republik Indonesia Nomor 1529/MENKES/ SK/X/2010, dikaitan dengan tahapan ketiga yang dilaksanakan dalam kelurahan siaga aktif adalah pelaksanaan musyawarah di tingkat kelurahan. Berdasarkan hasil observasi peneliti, musyawarah masyarakat kelurahan I dilaksanakan dengan tujuan untuk mendapatkan daftar masalah yang didapat melalui metode Focus Group 
Discussion, dimana petugas pelaksana kegiatan yaitu staf puskesmas menyebarkan kertas pada masing-masing perwakilan RW serta RT.

Perwakilan RW maupun RT yang telah menerima kertas tersebut, lalu menuliskan masalah yang ada di wilayahnya dengan berdiskusi bersama para kader kesehatan yang turut diundang dalam kegiatan musyawarah tersebut dengan didampingi oleh bidan kelurahan. Setelah kegiatan penulisan selesai, kertas yang telah dibagikan akan dikumpulkan dan dilakukan diskusi dalam forum musyawarah masyarakat kelurahan tersebut dengan dipimpin oleh pemimpin rapat. Pemimpin rapat merupakan salah satu petugas kesehatan dari puskesmas yang didampingi oleh staf kelurahan. Diskusi tersebut nanti akan menghasilkan prioritas masalah kesehatan yang disetujui oleh seluruh peserta musyawarah yang hadir, sehingga nanti prioritas masalah yang didapat akan dijadikan sebagai acuan utama dalam pembuatan pertanyaan untuk tahapan kelurahan siaga selanjutnya yaitu Survei Mawas Diri (SMD). Berdasarkan data, maka proses MMK I berdasarkan empat aspek penilaian ditampilkan pada tabel 1.

Kegiatan survei mawas diri berdasarkan hasil wawancara kepada bidan kelurahan dilaksanakan minimal terhadap $30 \mathrm{KK}$ pada masing-masing kelurahan dengan tenaga pelaksanaannya melibatkan peran aktif kader. Kader SMD menurut penjelasan dari bidan kelurahan sebelumnya telah mendapat pelatihan serta pengarahan, ketika akan melaksanakan survei. Selain itu kader yang ditunjuk tersebut adalah kader yang telah dilibatkan aktif sejak

Tabel 1. Pelaksanaan Kegiatan Musyawarah Masyarakat Kelurahan I

\begin{tabular}{|c|c|}
\hline Aspek & Bentuk Pelaksanaan Kegiatan Musyawarah Masyarakat Kelurahan I \\
\hline Pelaksana & $\begin{array}{l}\text { Pelaksana MMK I adalah pihak puskesmas yang berkoordinasi dengan } \\
\text { kelurahan. }\end{array}$ \\
\hline Kegiatan & $\begin{array}{l}\text { Kegiatan MMK I dilakukan untuk menentukan daftar masalah yang } \\
\text { di masyarakat. Kegiatan MMK I meliputi diskusi bersama yang } \\
\text { dihadiri oleh Lurah, Ketua RW, Ketua RT, Tokoh Masyarakat, Tokoh } \\
\text { Agama, Kader Kesehatan, Penggerak PKK yang berjumlah } 25 \text { dari } 25 \\
\text { undangan. }\end{array}$ \\
\hline Waktu pelaksanaan & Kegiatan MMK I dilakukan setahun sekali pada bulan Mei. \\
\hline Hasil kegiatan & $\begin{array}{l}\text { Hasil kegiatan MMK I adalah didapat prioritas masalah kesehatan } \\
\text { yang ada di masing-masing kelurahan, terbentuknya beberapa } \\
\text { pertanyaan sebagai acuan kuesioner Survey Mawas Diri. }\end{array}$ \\
\hline Pelaporan & $\begin{array}{l}\text { Laporan hasil pelaksanaan MMK I dibuat dalam bentuk laporan akhir } \\
\text { tahun yang dilakukan oleh pihak puskesmas yang ditujukan kepada } \\
\text { dinas kesehatan kota. }\end{array}$ \\
\hline
\end{tabular}

Tabel 2. Pelaksanaan kegiatan Survei Mawas Diri

\begin{tabular}{|c|c|}
\hline Aspek & Bentuk Pelaksanaan Kegiatan Survei Mawas Diri \\
\hline Pelaksana & Pelaksana SMD adalah kader kesehatan dan petugas Puskesmas \\
\hline Kegiatan & $\begin{array}{l}\text { Kegiatan SMD dilakukan dengan pengisian kuesioner pertanyaan } \\
\text { terhadap } 30 \mathrm{KK} \text { di kelurahan A dan Beserta } 40 \mathrm{KK} \text { di Kelurahan C. } \\
\text { Kegiatan dilakukan dengan mengunjungi sasaran survei. }\end{array}$ \\
\hline Waktu pelaksanaan & Waktu pelaksanaan dilakukan pada bulan Juli. \\
\hline Hasil kegiatan & $\begin{array}{l}\text { Hasil kegiatan SMD adalah } 10 \text { masalah kesehatan utama yang didapat } \\
\text { dari analisis instrumen survei di masing-masing kelurahan. }\end{array}$ \\
\hline Pelaporan & $\begin{array}{l}\text { Laporan hasil pelaksanaan SMD dibuat dalam bentuk laporan akhir } \\
\text { tahun yang dilakukan oleh pihak puskesmas yang ditujukan kepada } \\
\text { dinas kesehatan kota. }\end{array}$ \\
\hline Instrumen & $\begin{array}{l}\text { Instrumen yang digunakan dalam SMD tahun } 2017 \text { meliputi } 25 \text { butir } \\
\text { pertanyaan dengan pilihan jawaban berganda. }\end{array}$ \\
\hline
\end{tabular}


MMD I. Instrumen yang digunakan dalam SMD sendiri dibuat oleh staf puskesmas berdasarkan hasil pembuatan prioritas masalah pada MMK I, pertanyaan yang dikaji dalam SMD berdasarkan data laporan pelaksanaan SMD Tahun 2017 puskesmas $X$ Pertanyaan yang diajukan terdiri dari 25 butir pertanyaan, meliputi topik sebagai berikut : 1) Program Kesehatan Ibu dan Anak, 2) Program Keluarga Berencana, 3) Program Gizi, 4) Program Promosi Kesehatan, 5) Program Kesehatan Lingkungan, 6) Program Penanggulangan Penyakit-Penyakit Menular \& Imunisasi, 7) Program Anak Usia sekolah \& Remaja, 8) Program Penanggulangan Penyakit Tidak menular, terdiri dari Program kesehatan jiwa, Program Kesehatan indera, Program Kesehatan Gigi dan Mulut, serta 9) Program Penyehatan Tradisional. Aspek pelaksanaan SMD sendiri ditampilkan pada tabel 2 .

Kegiatan survei mawas diri terlaksana, kegiatan selanjutnya adalah pertemuan masyarakat kelurahan yang kedua atau biasa disebut musyawarah masyarakat kelurahan (MMK) II. MMK II dilakukan dengan tujuan menyajikan hasil SMD pada masing-masing kelurahan. Penyajian hasil SMD dilakukan dalam bentuk persentase pada masing-masing butir pertanyaan, setelah ditampilkan kepada seluruh peserta dan undangan yang hadir dilakukan diskusi untuk menentukan rencana tindak lanjut yang diharapkan dapat berjalan dengan efektif untuk menyelesaikan permasalahan kesehatan yang ada. Rencana tindak lanjut yang didapatkan ini disetujui oleh seluruh peserta MMK
II yang hadir, sehingga nantinya pihak puskesmas akan melaksanakan program penyelesaian masalah kesehatan sesuai dengan kesepakatan. Berdasarkan data yang ada, maka proses MMK II berdasarkan 5 aspek penilaian ditampilkan pada tabel 3. Pelaporan ketiga kegiatan yang telah dilaksanakan, kemudian dijadikan satu dalam laporan tahunan puskesmas.

Pedoman Pelaksanaan Kelurahan Siaga dalam Keputusan Menteri Kesehatan Republik Indonesia Nomor 1529/MENKES/ SK/X/2010 pertemuan masyarakat tingkat kelurahan dijabarkan dalam Bab III poin C, bertujuan sebagai 1) upaya sosialisasi mengenai masalah kesehatan yang dihadapi masyarakat dalam pengembangan kelurahan siaga aktif, 2) mencapai kesepakatan dalam tingkat prioritas masalah yang akan ditangani, 3) mencapai kesepakatan mengenai UKBM yang akan dibentuk maupun diaktifkan lagi, 4) menetapkan data maupun informasi dari potensi kelurahan, meliputi dukungan yang dibutuhkan dan alternatif sumber dukungan tersebut, serta 5) mengumpulkan dan meningkatkan semangat serta partisipasi dari warga masyarakat kelurahan dalam upaya mendukung pelaksanaan pengembangan kelurahan siaga aktif.

Pelaksanaan MMK dan SMD sendiri telah dicantumkan dalam PMK No.44 Tahun 2016 tentang Pedoman Manajemen Puskesmas, sehingga untuk pelaksanaannya masuk ke dalam RUK yang dibuat oleh pihak puskesmas sebagai program kegiatan tahunan. Hasil evaluasi berdasarkan beberapa peraturan yang telah disebut

Tabel 3. Pelaksanaan kegiatan Musyawarah Masyarakat Kelurahan II

\begin{tabular}{|c|c|}
\hline Aspek & Bentuk Pelaksanaan Kegiatan Musyawarah Masyarakat Kelurahan II \\
\hline Pelaksana & $\begin{array}{l}\text { Pelaksana MMK II adalah pihak puskesmas yang berkoordinasi dengan } \\
\text { kelurahan. }\end{array}$ \\
\hline Kegiatan & $\begin{array}{l}\text { Kegiatan MMK I dilakukan untuk menentukan daftar masalah yang di } \\
\text { masyarakat. kegiatan MMK I meliputi diskusi bersama yang dihadiri } \\
\text { oleh Lurah, Ketua RW, Ketua RT, Tokoh Masyarakat, Kader Kesehatan, } \\
\text { dan Penggerak PKK yang berjumlah } 32 \text { dari } 32 \text { undangan. }\end{array}$ \\
\hline Waktu pelaksanaan & Waktu pelaksanaan dilakukan pada bulan November. \\
\hline Hasil kegiatan & $\begin{array}{l}\text { Hasil kegiatan MMK II adalah tersampaikan hasil pelaksanaan SMD di } \\
\text { masing-masing kelurahan, terdapat } 10 \text { masalah utama, terbentuk } \\
\text { rencana tindak lanjut yang disepakati bersama. }\end{array}$ \\
\hline Pelaporan & $\begin{array}{l}\text { Laporan hasil pelaksanaan MMK II dibuat dalam bentuk laporan akhir } \\
\text { tahun yang dilakukan oleh pihak puskesmas yang ditujukan kepada } \\
\text { dinas kesehatan kota. }\end{array}$ \\
\hline
\end{tabular}


62 J urnal Promkes: The Indonesian J ournal of Health Promotion and Health Education Vol. 7 No. 1 (2019) 56-66. doi: 10.20473/jpk.V7.I1.2019.56-66

dapat dilihat pada tabel-tabel yang telah disajikan. Hasil evaluasi pelaksanaan kegiatan musyawarah masyarakat kelurahan I dapat dilihat pada Tabel 4.
Hasil evaluasi pelaksanaan kegiatan survey mawas diri dapat dilihat pada Tabel 5. Hasil evaluasi pelaksanaan kegiatan musyawarah masyarakat kelurahan II dapat dilihat pada Tabel 6.

Tabel 4. Evaluasi pelaksanaan kegiatan Musyawarah Masyarakat Kelurahan I

\begin{tabular}{|c|c|}
\hline \multicolumn{2}{|r|}{ Aspek Pelaksana } \\
\hline Pelaksanaan & $\begin{array}{l}\text { Pelaksana musyawarah masyarakat kelurahan I adalah petugas } \\
\text { Puskesmas X, dibantu oleh staf kelurahan. }\end{array}$ \\
\hline Standar & $\begin{array}{l}\text { dalam PMK No.44 Tahun } 2016 \text { tentang Pedoman Manajemen } \\
\text { Puskesmas poin tabel 1. Tahapan kegiatan siklus manajemen } \\
\text { puskesmas pada hlm } 12 \text {, pelaksana utama MMK adalah Kelurahan. }\end{array}$ \\
\hline Keterangan & $\begin{array}{l}\text { Kurang sesuai dengan PMK No. } 44 \text { Tahun } 2016 \text { tentang Pedoman } \\
\text { Manajemen Puskesmas karena pelaksanaan utama dalam kegiatan } \\
\text { MMK I ini adalah petugas puskesmas, mulai dari penyusunan } \\
\text { rangkaian kegiatan hingga penyampaian konten musyawarah. }\end{array}$ \\
\hline \multicolumn{2}{|r|}{ Aspek Kegiatan } \\
\hline Pelaksanaan & $\begin{array}{l}\text { Kegiatan yang dilakukan meliputi pembuatan daftar masalah } \\
\text { kesehatan yang dianggap masih banyak terjadi, serta pembuatan } \\
\text { prioritas masalah. }\end{array}$ \\
\hline Standar & $\begin{array}{l}\text { Pedoman Pelaksanaan Kelurahan Siaga dalam Keputusan Menteri } \\
\text { Kesehatan Republik Indonesia Nomor 1529/MENKES/SK/X/2010 Bab } \\
\text { III poin C MMK digunakan untuk upaya sosialisasi mengenai masalah } \\
\text { kesehatan yang dihadapi masyarakat dalam pengembangan kelurahan } \\
\text { siaga aktif dan mencapai kesepakatan dalam tingkat prioritas } \\
\text { masalah yang akan ditangani. }\end{array}$ \\
\hline Keterangan & $\begin{array}{l}\text { Sesuai dengan Pedoman Pelaksanaan Kelurahan Siaga dalam } \\
\text { Keputusan Menteri Kesehatan Republik Indonesia Nomor 1529/ } \\
\text { MENKES/SK/X/2010. }\end{array}$ \\
\hline \multicolumn{2}{|r|}{ Aspek Waktu Pelaksanaan } \\
\hline Pelaksanaan & Dilakukan pada bulan Mei . \\
\hline Standar & $\begin{array}{l}\text { dalam PMK No.44 Tahun } 2016 \text { tentang Pedoman Manajemen } \\
\text { Puskesmas poin tabel 1. Tahapan kegiatan siklus manajemen } \\
\text { puskesmas pada hlm 12, waktu pelaksanaan adalah awal Januari. }\end{array}$ \\
\hline Keterangan & $\begin{array}{l}\text { Kurang sesuai dengan pedoman, karena jarak bulan pelaksanaan } \\
\text { cukup jauh, dimana pada peraturan tercantum awal januari namun } \\
\text { pada kenyataannya dilaksanakan pada bulan kelima. }\end{array}$ \\
\hline \multicolumn{2}{|r|}{ Aspek Hasil Kegiatan } \\
\hline Pelaksanaan & $\begin{array}{l}\text { didapat prioritas masalah kesehatan yang ada di masing-masing } \\
\text { kelurahan, terbentuknya beberapa pertanyaan sebagai acuan } \\
\text { pembuatan pertanyaan kuesioner Survey Mawas Diri. }\end{array}$ \\
\hline Standar & $\begin{array}{l}\text { dalam PMK No.44 Tahun } 2016 \text { tentang Pedoman Manajemen } \\
\text { Puskesmas poin tabel 1. Tahapan kegiatan siklus manajemen } \\
\text { puskesmas pada hlm 12, hasil yang diharapkan adalah mendapat } \\
\text { analisa situasi. }\end{array}$ \\
\hline Keterangan & Sesuai dengan peraturan. \\
\hline \multicolumn{2}{|r|}{ Aspek Pelaporan } \\
\hline Pelaksanaan & $\begin{array}{l}\text { Evaluasi dilaksanakan bersama saat diselenggarakan musyawarah } \\
\text { kedua, serta dalam bentuk laporan tahunan pada akhir tahun. }\end{array}$ \\
\hline Standar & $\begin{array}{l}\text { Dilakukan dalam dua periode yaitu evaluasi tengah periode (midterm } \\
\text { evaluation) dan akhir tahun melalui PKP. }\end{array}$ \\
\hline Keterangan & Sesuai dengan peraturan. \\
\hline
\end{tabular}


Tabel 5. Evaluasi Pelaksanaan Kegiatan Survei Mawas Diri

\begin{tabular}{|c|c|}
\hline \multicolumn{2}{|r|}{ Aspek Pelaksana } \\
\hline Pelaksanaan & $\begin{array}{l}\text { Pelaksana SMD dilakukan oleh kader SMD yang telah ditunjuk serta } \\
\text { Bidan kelurahan sebagai petugas kesehatan. }\end{array}$ \\
\hline Standar & $\begin{array}{l}\text { Dalam Juknis biaya pengembangan desa siaga aktif Bab III poin B } \\
\text { Langkah-langkah pengembangan desa dan kelurahan siaga aktif, } \\
\text { pelaksana SMD adalah Kader dan tokoh masyarakat. }\end{array}$ \\
\hline Keterangan & Sesuai dengan peraturan. \\
\hline \multicolumn{2}{|r|}{ Aspek Kegiatan } \\
\hline Pelaksanaan & $\begin{array}{l}\text { Kegiatan SMD meliputi kegiatan pengumpulan data primer melalui } \\
\text { pertanyaan yang dibuat dalam bentuk kuesioner mengenai masalah } \\
\text { kesehatan yang dihadapi yang disusun oleh petugas puskesmas. }\end{array}$ \\
\hline Standar & $\begin{array}{l}\text { dalam PMK No.44 Tahun } 2016 \text { tentang Pedoman Manajemen } \\
\text { Puskesmas, kegiatan SMD ditujukan untuk mengenali keadaan dan } \\
\text { masalah yang ada di masyarakat. Diambil dengan menggunakan } \\
\text { metode instrumen SMD yang disusun puskesmas. }\end{array}$ \\
\hline Keterangan & Sesuai dengan peraturan. \\
\hline \multicolumn{2}{|r|}{ Aspek Waktu Pelaksanaan } \\
\hline Pelaksanaan & SMD dilaksanakan pada bulan Juli, satu kali dalam setahun. \\
\hline Standar & $\begin{array}{l}\text { Dalam Juknis biaya pengembangan desa siaga aktif Bab III poin B } \\
\text { mengenai langkah-langkah pengembangan desa dan kelurahan siaga } \\
\text { aktif, waktu pelaksanaan SMD minimal setahun sekali. }\end{array}$ \\
\hline Keterangan & Sesuai dengan peraturan \\
\hline \multicolumn{2}{|r|}{ Aspek Hasil Kegiatan } \\
\hline Pelaksanaan & $\begin{array}{l}\text { Hasil SMD adalah } 10 \text { masalah kesehatan utama berdasarkan } \\
\text { pengolahan jawaban responden SMD. }\end{array}$ \\
\hline Standar & $\begin{array}{l}\text { dalam PMK No.44 Tahun } 2016 \text { tentang Pedoman Manajemen } \\
\text { Puskesmas, SMD dapat memberi informasi mengenai masalah yang } \\
\text { terjadi di masyarakat. }\end{array}$ \\
\hline Keterangan & Sesuai dengan peraturan. \\
\hline \multicolumn{2}{|r|}{ Aspek Pelaporan } \\
\hline Pelaksanaan & $\begin{array}{l}\text { Pelaporan SMD disampaikan kepada seluruh pihak terkait pada saat } \\
\text { MMK II dan pembuatan laporan tahunan Puskesmas. }\end{array}$ \\
\hline Standar & $\begin{array}{l}\text { Dalam Juknis biaya pengembangan desa siaga aktif Bab III poin B } \\
\text { langkah-langkah pengembangan desa dan kelurahan siaga aktif, } \\
\text { pengolahan dan analisis data hasil SMD dilakukan dengan bimbingan } \\
\text { petugas, dan dibahas dalam MMK II. }\end{array}$ \\
\hline Keterangan & Sesuai dengan peraturan. \\
\hline \multicolumn{2}{|r|}{ Aspek Instrumen } \\
\hline Pelaksanaan & $\begin{array}{l}\text { Instrumen SMD disusun berdasarkan hasil analisis daftar dan prioritas } \\
\text { masalah yang dilakukan pada MMK I dan dijadikan acuan dalam } \\
\text { pembuatan item pertanyaan oleh petugas puskesmas. }\end{array}$ \\
\hline Standar & $\begin{array}{l}\text { Instrumen SMD disusun oleh puskesmas sesuai dengan masalah yang } \\
\text { dihadapi. }\end{array}$ \\
\hline Keterangan & Sesuai dengan peraturan. \\
\hline
\end{tabular}

Pelaksanaan Kelurahan siaga yang mencakup kegiatan SMD dan MMK I dan II memiliki beberapa peraturan yang dijadikan acuan dalam pelaksanaannya, berdasarkan hasil evaluasi yang dilakukan ada tiga pedoman yang dijadikan acuan.
Penggunaan ketiga acuan ini dilakukan karena pada kenyataannya pelaksanaan SMD dan MMK ini tahapannya akan berubah sesuai dengan kondisi pada masing-masing wilayah yang artinya masing-masing wilayah dapat melaksanakan masing-masing 
Tabel 6. Evaluasi Pelaksanaan Kegiatan Musyawarah Masyarakat Kelurahan II

\begin{tabular}{|c|c|}
\hline \multicolumn{2}{|r|}{ Aspek Pelaksana } \\
\hline $\begin{array}{l}\text { Pelaksanaan } \\
\text { Standar }\end{array}$ & $\begin{array}{l}\text { Dilakukan oleh petugas puskesmas dibantu oleh staf kelurahan. } \\
\text { dalam PMK No.44 Tahun } 2016 \text { tentang Pedoman Manajemen } \\
\text { Puskesmas poin tabel 1. Tahapan kegiatan siklus manajemen } \\
\text { puskesmas pada hlm 12, pelaksana utama MMK adalah pihak } \\
\text { kelurahan. }\end{array}$ \\
\hline Keterangan & $\begin{array}{l}\text { Kurang sesuai dengan PMK No.44 Tahun } 2016 \text { tentang Pedoman } \\
\text { Manajemen Puskesmas. }\end{array}$ \\
\hline \multicolumn{2}{|r|}{ Aspek Kegiatan } \\
\hline Pelaksanaan & $\begin{array}{l}\text { Kegiatan MMK I bertujuan untuk melakukan pembahasan hasil } \\
\text { SMD serta pembuatan rencana tindak lanjut untuk menanggulangi } \\
\text { permasalahan kesehatan yang ada. }\end{array}$ \\
\hline Standar & $\begin{array}{l}\text { Dalam Juknis biaya pengembangan desa siaga aktif Bab III poin B } \\
\text { langkah-langkah pengembangan desa dan kelurahan siaga aktif, } \\
\text { MMK dilakukan dalam rangka pembahasan hasil SMD, serta prioritas } \\
\text { masalah yang akan diatasi. }\end{array}$ \\
\hline Keterangan & $\begin{array}{l}\text { Sesuai dengan peraturan. Karena pelaksanaan utama dari MMK II ini } \\
\text { sama seperti MMK sebelumnya yaitu petugas puskesmas. }\end{array}$ \\
\hline \multicolumn{2}{|r|}{ Aspek Waktu Pelaksanaan } \\
\hline Pelaksanaan & Dilaksanakan setelah kegiatan SMD sudah selesai. \\
\hline Standar & $\begin{array}{l}\text { Dalam Juknis biaya pengembangan desa siaga aktif Bab III poin B } \\
\text { langkah-langkah pengembangan desa dan kelurahan siaga aktif, MMK } \\
\text { dilakukan setelah pelaksanaan SMD selesai. }\end{array}$ \\
\hline Keterangan & Sesuai dengan peraturan. \\
\hline \multicolumn{2}{|r|}{ Aspek Hasil Kegiatan } \\
\hline Pelaksanaan & $\begin{array}{l}\text { MMK II menghasilkan rencana tindak lanjut penanggulangan masalah } \\
\text { yang disepakati bersama oleh peserta musyawarah. }\end{array}$ \\
\hline Standar & $\begin{array}{l}\text { dalam PMK No.44 Tahun } 2016 \text { tentang Pedoman Manajemen } \\
\text { Puskesmas poin tabel 1. Tahapan kegiatan siklus manajemen } \\
\text { puskesmas pada hlm 12, keluaran MMK adalah usulan kebutuhan } \\
\text { pelayanan kesehatan msayarakat yang sesuai dengan harapan } \\
\text { rasional }\end{array}$ \\
\hline Keterangan & Sesuai dengan peraturan. \\
\hline \multicolumn{2}{|r|}{ Aspek Pelaporan } \\
\hline Pelaksanaan & $\begin{array}{l}\text { Pelaporan hasil MMK II dilakukan pada akhir tahun serta akan sedikit } \\
\text { disinggung dalam MMK I pada tahun selanjutnya. }\end{array}$ \\
\hline Standar & $\begin{array}{l}\text { Dilakukan dalam dua periode yaitu evaluasi tengah periode (midterm } \\
\text { evaluation) dan akhir tahun melalui PKP. }\end{array}$ \\
\hline Keterangan & Sesuai dengan peraturan. \\
\hline
\end{tabular}

tahapan sesuai dengan hasil perumusan tahapan yang disesuaikan agar dalam pelaksanaannya dapat lebih mudah. Dari analisis yang telah dilakukan pada masingmasing tahapan ketidaksesuaian banyak terjadi pada aspek pelaksana kegiatan. Hal ini berdasarkan hasil wawancara dengan bidan kelurahan yang dapat terjadi karena adanya pergeseran fungsi pelaksana Kelurahan Siaga, dimana pada peraturan menyatakan pelaksana utamanya adalah pihak kelurahan yang pada kenyataannya surat tugas pelaksanaan dan pengembangan Kelurahan Siaga justru jatuh pada puskesmas.

Pergeseran peran pelaksana dapat memberikan kontribusi negatif terhadap pelaksanaan kegiatan. Terutama dalam hal pelaporan dan evaluasi yang akan dilakukan, sedangkan pada kegiatan SMD pelaksana kegiatan sudah sangat sesuai dengan peraturan yang ada dimana peran aktif kader dan TOMA dilibatkan secara langsung untuk melaksanakan survei 
pada masyarakat di wilayah kelurahan. Hal ini juga sesuai dengan tujuan konsep pemberdayaan masyarakat (Notoadmojdo, 2010), bahwa pemberdayaan masyarakat bertujuan untuk menumbuhkan pemikiran, kemauan serta kemampuan dalam mengatasi masalah kesehatan yang bersumber pada masyarakat itu sendiri, jadi peran aktif kader dalam pelaksanaan kegiatan SMD menunjang tujuan pemberdayaan masyarakat yang sesungguhnya.

Kegiatan MMK sendiri bertujuan untuk mendapat analisis situasi masalah kesehatan yang terjadi. Tahapan pemberdayaan Masyarakat dalam bidang kesehatan ada tujuh (Soekanto, 1987). Tahap pertama yaitu tahapan pengkajian (assessment), dimana pada tahap ini dilakukan untuk mengidentifikasi permasalahan kesehatan yang ada, serta kebutuhan akan pemenuhan kesehatan yang dirasakan (feel needs). Pada tahapan inilah kegiatan musyawarah masyarakat kelurahan I sesuai untuk dengan konsep program dengan pendekatan pemberdayaan masyarakat. Kegiatan survei secara langsung kepada masyarakat pun dapat menghasilkan gambaran masalah yang sesuai dengan kenyataan dalam masyarakat, sehingga pelaksanaan survei mawas diri atau juga disebut dengan community self survey ini dirasa tepat dilakukan untuk mengatasi permasalahan secara efektif.

Waktu pelaksanaan kegiatan MMK yang pertama masih kurang sesuai dengan pedoman yang ada. Hal tersebut harusnya dilakukan pada awal tahun kerja puskesmas, namun justru dilakukan pada pertengahan tahun yakni bulan kelima. Waktu pelaksanaan yang sangat mundur ini dapat menyebabkan kurang optimalnya pelaksanaan intervensi atau rencana tindak lanjut penyelesaian masalah karena jadwal kegiatan yang sangat mundur, sehingga berisiko pada tidak tercapainya tujuan rencana tindak lanjut tersebut dan masalah kesehatan yang ada akan masih tetap ada pada tahun berikutnya.

Kegiatan musyawarah ini sebaiknya dilaksanakan harus sesuai dengan pedoman yang ada. Pembuatan instrumen SMD sendiri sudah sesuai dengan peraturan yang ada, sehingga hasil yang didapat mampu menggambarkan permasalahan yang ada, selain itu topik yang diangkat dalam survei juga menggambarkan kegiatan-kegiatan yang ada dalam Kelurahan Siaga. Metode survei secara langsung pada masyarakat ini sendiri juga sesuai dengan tahapan pemberdayaan masyarakat yang ketiga, dimana petugas sebagai agen perubahan mampu melibatkan peran aktif warga masyarakat untuk menelaah masalah kesehatan yang mereka hadapi.

Aspek yang terakhir adalah aspek pelaporan. Pada aspek ini, pelaporan meliputi upaya evaluasi yang dilakukan pada tingkat puskesmas. Hasil wawancara pada bidan kelurahan bahwa evaluasi kegiatan musyawarah masyarakat kelurahan dilakukan pada akhir pelaksanaan kegiatan. Hasil evaluasi dilakukan terhadap tiga komponen utama berdasarkan waktu pelaksanaan kegiatan serta sasarannya, dibedakan menjadi tiga yaitu dari segi input, proses, dan output (Muninjaya, 2011). Evaluasi input dilakukan pada jumlah peserta yang hadir, tempat kegiatan, hingga prose koordinasi antar pihak terkait, evaluasi proses dilakukan terhadap waktu pelaksanaan, kehadiran peserta serta peran aktif peserta saat musyawarah, dan untuk evaluasi hasil apakah musyawarah dapat menghasilkan keluaran yang diharapkan pada musyawarah, dimana berdasarkan hasil analisis laporan pelaksanaan MMK I dan MMK II puskesmas X menjelaskan keluaran yang diharapkan telah sesuai dengan pedoman yang ada. Pelaksanaan evaluasi pada setiap hasil ini juga dilakukan dalam bentuk laporan tahunan yang dibuat pada akhir tahun masa kerja dari puskesmas, sehingga dari adanya evaluasi serta pelaporan yang dibuat tersendiri penyampaian serta penyebarluasan hasil kinerja dan kondisi permasalahan yang dihadapi di masyarakat dapat lebih mudah untuk dilakukan.

\section{SIMPULAN}

Pelaksanaan musyawarah masyarakat kelurahan dan survei mawas diri di wilayah puskesmas $X$ setelah dilakukan pembahasan dapat disimpulkan bahwa

1. Aspek pelaksana untuk musyawarah masyarakat kelurahan masih belum sesuai dengan ketentuan yang ada, sedangkan untuk SMD pelaksananya sudah sesuai. 
2. Aspek pelaksanaan MMK dan SMD sudah sesuai dengan tujuan yang telah ditetapkan.

3. Aspek waktu pelaksanaan dalam kegiatan musyawarah masyarakat kelurahan belum sesuai, sedangkan untuk SMD sudah sesuai dengan pedoman.

4. Hasil atau keluaran yang diharapkan pada tahapan MMK I, Survei mawas diri, dan MMK II sudah sesuai dengan pedoman yang berlaku.

5. Aspek pelaporan untuk musyawarah masyarakat kelurahan dan survey mawas diri sudah sesuai dengan pedoman yang ada.

Kelurahan siaga sendiri dapat berjalan dengan baik sesuai dengan konsepnya yaitu menjadikan masyarakat sehat yang mandiri. Secara keseluruhan tahapan kegiatan dalam kelurahan siaga di puskesmas $X$ yang meliputi musyawarah masyarakat kelurahan I maupun II telah dilaksakanan dengan sesuai. Pelaksanaan SMD mayoritas aspek pelaksanaannya telah memenuhi pedoman yang ada.

\section{DAFTAR PUSTAKA}

Juknis Biaya Pengembangan Desa Siaga Aktif dari Kemenkes RI Tahun 2010.
Keputusan Menteri Kesehatan Nomor 564/Menkes/SK/VIII/2006 Tentang Pedoman Pelaksanaan Pengembangan Desa Siaga.

Keputusan Menteri Kesehatan Republik IndonesiaNomor 1529/MENKES/SK/ X/2010 Tentang Pedoman Pelaksanaan Pengembangan Desa Siaga.

Laporan musyawarah masyarakat kelurahan (MMK) I Puskesmas X tahun 2017.

Laporan musyawarah masyarakat kelurahan (MMK) II Puskesmas X tahun 2017.

Laporan survei mawas diri (SMD) Puskesmas $X$ tahun 2017.

Muninjaya, Gde AA. 2011. Manajemen Mutu Pelayanan Kesehatan. Jakarta: EGC.

Notoatmodjo, Soekidjo. 2010. Promosi Kesehatan. Edisi Revisi. Jakarta: Rineka Cipta.

PMK No.44 Tahun 2016 tentang Pedoman Manajemen Puskesmas.

Soekanto, Soerjono. 2010. Sosiologi Suatu Pengantar. Jakarta. PT Rajagrafindo. Persada

Undang-undang Republik Indonesia Nomor 17 Tahun 2007 tentang pembangunan Jangka Panjang Nasional untuk tahun 2005-2025

Widyaningsih, V. 2008. Rancangan Penelitian/ Research Design An Overview. 